\title{
Fabrication of an Electrochemical Sensor for Helicobacter pylori in Excrement Based on a Gold Electrode
}

\author{
Puji Peng ${ }^{1, *}$, Feng $X u^{1}$, Yuying $X u^{2}$ and Shuang Sun ${ }^{1}$ \\ ${ }^{1}$ Zhengzhou University; Zhengzhou, Henan, 450052, China \\ ${ }^{2}$ Henan University of Chinese Medicine, Zhengzhou, Henan 450000, China \\ *E-mail: pengpuji852@163.com
}

doi: $10.20964 / 2017.10 .19$

Received: 16 June 2017 / Accepted: 29 July 2017 / Published: 12 September 2017

\begin{abstract}
This study presented the determination of Helicobacter pylori using a gold electrode (AuE)-based electrochemical biosensor in which the electroactive label was $\beta$-cyclodextrin $(\beta-C D)$. The covalent immobilization of a thiol-decorated single-stranded DNA probe on the AuE surface occurred through the formation of a $\mathrm{Au}-\mathrm{S}$ bond. The DNA hybridization was monitored via the differential pulse voltammetry (DPV) method, where the electrochemical signals for reduction of the $\beta$-CD bound to the double-stranded DNA (dsDNA) were measured. The electrochemical signal was linearly related to the target DNA concentration $(0.3 \mathrm{nM}-0.24 \mu \mathrm{M})$ when measured under optimal conditions, and the limit of detection (LOD) was determined to be as low as $0.15 \mathrm{nM}$, suggesting that measurements with our developed biosensor were highly repeatable and reproducible. In addition, our proposed biosensor was successfully applied to the determination of Helicobacter pylori in excrement.
\end{abstract}

Keywords: Electrochemical biosensor; $\beta$-cyclodextrin; Helicobacter pylori; Excrement; Thiol modification

\section{FULL TEXT}

(C) 2017 The Authors. Published by ESG (www.electrochemsci.org). This article is an open access article distributed under the terms and conditions of the Creative Commons Attribution license (http://creativecommons.org/licenses/by/4.0/). 